Money Unmade 
This page intentionally left blank 


\section{Money Unmade}

Barter and the Fate of Russian Capitalism

\section{DAVID WOODRUFF}

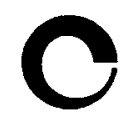

CORNELL UNIVERSITY PRESS ITHACAANDLONDON 


\section{Copyright (1) 1999 by Cornell University}

All rights reserved. Except for brief quotations in a review, this book, or parts thereof, must not be reproduced in any form without permission in writing from the publisher. For information, address Cornell University Press, Sage House, 512 East State Street, Ithaca, New York 14850.

First published 1999 by Cornell University Press First printing, Cornell Paperbacks, 2000

Printed in the United States of America

Cornell University Press strives to use environmentally responsible suppliers and materiais to the fullest extent possible in the publishing of its books. Such materials include vegetable-based, low-VOC inks and acid-free papers that are recycled, totally chiorine-free, or partly composed of nonwood fibers. Books that bear the logo of the FSC (Fonest Stewardship Council) use paper taken from forests that have been inspected and certified as meeting the highest standards for environmental and social responsibility. For further information, visit our website at muw.cornellpress.cornell.edu.
Library of Congress Cataloging-in-Publication Data

Woodruff, David, 1967-

Money unmade : barter and the fate of Russian capitalism / David Woodruff.

p. $\mathrm{cm}$.

Includes index.

ISBN 0-8014-3660-5 (cloth: alk paper)

ISBN 0-8014-8694-7 (pbk: alk, paper)

1. Monetary policy-Russia (Federation)

2. Barter-Russia (Federation)

3. Financial crises-Russia (federation)

4. Russia (Federation)-Economic conditions-1991I.Title.

HG1080.2.W66 1999

$322.4^{\prime} 6^{\prime} 0947-\mathrm{dc} 21$

Cloth printing

$\begin{array}{lllllllll}10 & 9 & 8 & 7 & 6 & 5 & 4 & 3 & 2\end{array}$

Paperback printing

$\begin{array}{llllllllll}10 & 9 & 8 & 7 & 6 & 5 & 4 & 3 & 2 & 1\end{array}$ 
To Yuliya

for life 
The world is full of money-talk; economists are our new wise men. . . . Never trust them; trust only the novelists, those deeper bankers who spend their time trying to turn pieces of printed paper into value, but never pretend that the result is anything more than a useful fiction.

-Malcom Bradbury, Rates of Exchange, 1983 